\title{
Ectopic overexpression of the aluminum-induced protein gene from Panax ginseng enhances heavy metal tolerance in transgenic Arabidopsis
}

\author{
Moon-Gi Jang • Yu-Jin Kim • Gyu-Hwan Jang • \\ Johan Sukweenadhi · Woo-Saeng Kwon • \\ Deok-Chun Yang
}

Received: 6 February 2014/ Accepted: 17 May 2014/Published online: 1 June 2014

(C) Springer Science+Business Media Dordrecht 2014

\begin{abstract}
Aluminum (Al), one of the most abundant metals in agricultural soils, significantly limits crop growth and productivity in acidic soil by inhibiting root elongation. $\mathrm{Al}$ ions, especially $\mathrm{Al}^{3+}$, have a toxic effect on both plant and animal cells under low-pH conditions. We first isolated and characterized aluminum-induced protein (AIP) cDNA from a 4-year-old root of Panax ginseng Meyer. This cDNA encodes an open reading frame of $711 \mathrm{bp}$ with a deduced amino acid sequence of 236 residues. The calculated molecular mass of the mature protein is approximately $58.9 \mathrm{kDa}$ with a predicated isoelectric point of 5.13. The Panax ginseng AIP $(P g A I P)$ contains a domain also present in wheat aluminuminduced protein 7 (Wali7) and shares homology with the AIPs of other species, including Codonopis and Arabidopsis. The $P g A I P$ gene was abundantly expressed in the plant's leaves and was up-regulated by $\mathrm{Al}$ exposure. The functional role of $P g A I P$ in Al tolerance was further validated through its overexpression in Arabidopsis. Transgenic Arabidopsis plants overexpressing the $P g A I P$ gene showed enhanced Al tolerance in terms of root growth when compared to wild-type plants, suggesting $P g A I P$ is important in plant defense against Al toxicity. Confocal analysis of CFP-tagging PgAIP in Arabidopsis showed subcellular localization in the plasma membrane. Our results suggest that PgAIP in the plasma
\end{abstract}

Electronic supplementary material The online version of this article (doi:10.1007/s11240-014-0516-2) contains supplementary material, which is available to authorized users.

Moon-Gi Jang and Yu-Jin Kim have equally contributed to this work.

M.-G. Jang · Y.-J. Kim · G.-H. Jang · J. Sukweenadhi ·

W.-S. Kwon · D.-C. Yang ( $\bowtie)$

Department of Oriental Medicinal Materials and Processing,

College of Life Science, Kyung Hee University,

Suwon 449-701, Korea

e-mail: dcyang@khu.ac.kr membrane plays an important role in the protection of plant cells against heavy metal exposure.

Keywords Aluminum-induced protein · Gene expression · Heavy metal · Panax ginseng · Wali7

$\begin{array}{ll}\text { Abbreviations } \\ \text { AIP } & \text { Aluminum-induced protein } \\ \text { Al } & \text { Aluminum } \\ \text { cDNA } & \text { Complementary DNA } \\ \text { EST } & \text { Expressed sequence tag } \\ \text { ORF } & \text { Open reading frame } \\ \text { qRT- } & \text { Quantitative reverse transcription-polymerase } \\ \text { PCR } & \text { chain reaction } \\ \text { HM } & \text { Heavy metal } \\ \text { Wali7 } & \text { Wheat aluminum-induced protein } 7\end{array}$

\section{Introduction}

In many parts of the world, agricultural soils are contaminated with heavy metals that pose a serious health hazard to humans, animals, plants, and soil microorganisms (Ghnaya et al. 2010). Aluminum (Al) is the most abundant metal (Goodwin and Sutter 2009), composing approximately $7.5 \%$ of the elements in the earth' crust (Haug and Foy 1984). Although $\mathrm{Al}$ is an important mineral in plant growth and development (Kim et al. 2004), it has a toxic effect under low-pH conditions (Ezaki et al. 2004). Present in over $50 \%$ of the world's arable lands (von Uexküll and Mutert 1995), Al toxicity in acidic soils is a major factor limiting crop growth and productivity by inhibiting root elongation (Kochian 1995; Goodwin and Sutter 2009). The inhibition of root elongation impairs the uptake of water 